\title{
Evaluation of chemokine receptors (CCRs) expression on peripheral blood T-lymphocyte subsets in patients with thoracic aortic aneurysm
}

\author{
Kaushal Kishore Tiwari $^{1,2}$, Silverio Sbrana ${ }^{3}$, Stefano Bevilacqau ${ }^{2}$, Tommaso Gasbari ${ }^{2}$, Filippo \\ Santarelli ${ }^{2}$, Marco Solinas ${ }^{2}$, Mattia Glauber ${ }^{2}$ \\ ${ }^{1}$ Department of Cardiothoracic and Vascular Surgery, College of Medical Sciences, Teaching Hospital, \\ Bharatpur-10, Chitwan, Nepal \\ ${ }^{2}$ Department of Adult Cardiac Surgery, G. Paquinucci Heart Hospital, Massa, Italy \\ ${ }^{3}$ Flowcytometry Laboratory, CNR, Institute of Clinical Physiology, Pisa, Italy.
}

\section{Correspondence \\ Dr Kaushal K Tiwari \\ Department of Cardiothoracic \\ and Vascular Surgery, \\ College of Medical Sciences, \\ Teaching Hospital, Bharatpur-10, \\ Chitwan, Nepal \\ Email: drkaushalkt@yahoo.com}

DOI: http://dx.doi.org/10.3126/ jcmsn.v12i1.14717

\begin{abstract}
Background \& Objectives: Mortality and morbidity from the complication of aortic aneurysm remain very high. Aortic size index, which classify thoracic aortic aneurysm patients in three risk groups for aortic rupture prediction. Recent data support that aortic wall remodeling is a dynamic process with active involvement of the chronic inflammation and immunological system. Aim of our study is to evaluate expression level of chemokine receptors known to be involved in the Tcells migration and to correlate them with aortic size index. Materials \& Methods: Total 20 patients undergoing surgery for ascending aortic aneurysm and/or aortic valve surgery were enrolled. Aortic size index was calculated. Preoperatively blood samples collected. By flowcytometry and dual parameter dot plot technology percentage of positivity of CCR5 on these T-cell subsets were quantified. Results: Mean age of the patients was $67 \pm 5.93$ years. Majority of patients had hypertension. Mean ascending aortic diameter was $42.1 \pm 8.14 \mathrm{~mm}$. Mean Aortic size Index was $22.21 \pm 3.38 \mathrm{~mm} / \mathrm{m}^{2}$. A statistical significance has observed between aortic size index and the expression of CCR5 on total CD4 positive T-cells (p-0.0949), and between aortic size index and CCR5 expression on the total CD3 positive T-cells (p-0.0293). Significant correlation observed between ASI and CCR5 expression on the CD8+/CD3+ T-cell subset (p-0.0183). Similarly, strong positive relationship between ASI and the expression of CCR5 on the cytotoxic CD28-/CD4+ T-cell subset (p-0.0055). Activated state of cytotoxic CD28 -/CD4+ cell also correlated with aortic size index (p-0.0668). Conclusion: We conclude that T-cell mediated cytotoxic mechanism driven by CCR5 play an important role in the pathophysiology of the thoracic aortic aneurysm.
\end{abstract}

Key words: Aor tic size index, CCR5, thoracic aortic aneurysm

Citation: Tiwari KK, Sbrana S, Bevilacqau S, Gasbari T, Santarelli F, Solinas M, Glauber M. Evaluation of chemokine receptors (CCRs) expression on peripheral blood T-lymphocyte subsets in patients with thoracic aortic aneurysm. JCMS Nepal. 2016;12(1):23-7.

\section{INTRODUCTION}

About a century ago, Sir William Osler stated that there is no disease more conducive to clinical humility than aneurysm of aorta. ${ }^{1}$ This notation remain true in spite of all the recent developments in the field of medicine. Mortality and morbidity from the complication of aortic aneurysm remain very high. It is because aortic aneurysm grows slowly and silently until it dissects or ruptures. In case of dissection and rupture mortality increases as high as $90 \%$. In USA, it remains one of the leading

\section{cause of death. $^{2}$}

Cumulative and yearly risks of aortic dissection and rupture increase as the aneurysm size increases. Prophylactic aortic surgery, to avoid serious complications, is recommended at a diameter of 5.5 $\mathrm{cm}$ in otherwise normal patient, while $5 \mathrm{~cm}$ in a Marfan's patient. ${ }^{3}$

To classify patients with aortic aneurysm, several criteria have been proposed. One of them is Aortic size index, which classify these patients in three risk groups for aortic rupture prediction. It ranges 
from $4 \%$ yearly to $20 \%$ yearly risk of rupture in some patients with higher Aortic size index ${ }^{4}$ (Fig $1)$.

Pathophysiology of ascending aortic aneurysm is a complex process. Historically, it was supposed that aortic dilation and strength reduction of the aneurysmatic aortic wall were exclusively related to primary connective tissue alterations. Recent data support that aortic wall remodeling is a dynamic process with active involvement of the chronic inflammation and immunological system.

\section{Aim of the study}

Aim of our study is to evaluate expression level of chemokine receptors known to be involved in the $\mathrm{T}$ -cells migration and to correlate them with aortic size index, which is a predictor of the negative events in the patients with thoracic aortic aneurysm.

\section{MATERIALS AND METHODS}

In this prospective study, we have enrolled 20 patients undergoing surgery for ascending aortic aneurysm and/or aortic valve surgery in the G.
Table 1: General characteristics of the patients

\begin{tabular}{|l|l|}
\hline Characteristic & $\begin{array}{l}\text { Value (Mean } \pm \text { SD) or } \\
\text { N }(\%)\end{array}$ \\
\hline Age & $67.9 \pm 5.93$ \\
\hline Male & 12 patients $(60 \%)$ \\
\hline Smoker & 6 patients $(30 \%)$ \\
\hline Diabetes & 3 patients $(5 \%)$ \\
\hline Hypertension & 13 patients $(65 \%)$ \\
\hline $\begin{array}{l}\text { Ascending } \\
\text { diameter }\end{array}$ & $42.1 \pm 8.14 \mathrm{~mm}$ \\
\hline Aortic regurgitation & 14 patients $(70 \%)$ \\
\hline Aortic stenosis & 6 patients $(30 \%)$ \\
\hline Bicuspid Aortic Valve & 6 patients $(30 \%)$ \\
\hline Aortic size Index & $22.21 \pm 3.38 \mathrm{~mm} / \mathrm{m}^{2}$ \\
\hline
\end{tabular}

\begin{tabular}{|c|c|c|c|c|c|c|c|c|c|c|}
\hline \multirow[b]{2}{*}{ BSA } & \multicolumn{9}{|c|}{ Aortic size $(\mathrm{cm})$} & \multirow[b]{2}{*}{8.0} \\
\hline & 3.5 & 4.0 & 4.5 & 5.0 & 5.5 & 6.0 & 6.5 & 7.0 & 7.5 & \\
\hline 1.30 & 2.69 & 3.08 & 3.46 & 3.85 & 4.23 & 4.62 & 5.00 & 5.38 & 5.77 & 6.1 \\
\hline 1.40 & 2.50 & 2.86 & 3.21 & 3.57 & 3.93 & 4.29 & 4.64 & 5.00 & 5.36 & 5.71 \\
\hline 1.50 & 2.33 & 2.67 & 3.00 & 3.33 & 3.67 & 4.00 & 4.33 & 4.67 & 5.00 & 5.3 \\
\hline 1.60 & 2.19 & 2.50 & 2.80 & 3.13 & 3.44 & 3.75 & 4.06 & 4.38 & 4.69 & 5.0 \\
\hline 1.70 & 2.05 & 2.35 & 2.65 & 2.94 & 3.24 & 3.53 & 3.82 & 4.12 & 4.41 & 4.7 \\
\hline 1.80 & 1.94 & 2.22 & 2.50 & 2.78 & 3.06 & 3.33 & 3.61 & 3.89 & 4.17 & 4.4 \\
\hline 1.90 & 1.84 & 2.11 & 2.37 & 2.63 & 2.89 & 3.16 & 3.42 & 3.68 & 3.95 & 4.2. \\
\hline 2.00 & 1.75 & 2.00 & 2.25 & 2.50 & 2.75 & 3.00 & 3.25 & 3.50 & 3.75 & 4.00 \\
\hline 2.10 & 1.67 & 1.90 & 2.14 & 2.38 & 2.62 & 2.86 & 3.10 & 3.33 & 3.57 & $3.8 \mathrm{r}$ \\
\hline 2.20 & 1.59 & 1.82 & 2.05 & 2.27 & 2.50 & 2.72 & 2.95 & 3.18 & 3.41 & 2.6 \\
\hline 2.30 & 1.52 & 1.74 & 1.96 & 2.17 & 2.39 & 2.61 & 2.83 & 3.04 & 3.26 & 3.4 \\
\hline 2.40 & 1.46 & 1.67 & 1.88 & 2.08 & 2.29 & 2.50 & 2.71 & 2.92 & 3.13 & 3.3. \\
\hline 2.50 & 1.40 & 1.60 & 1.80 & 2.00 & 2.20 & 2.40 & 2.60 & 2.80 & 3.00 & 3.2 \\
\hline
\end{tabular}

Fig 1: Aortic size index chart

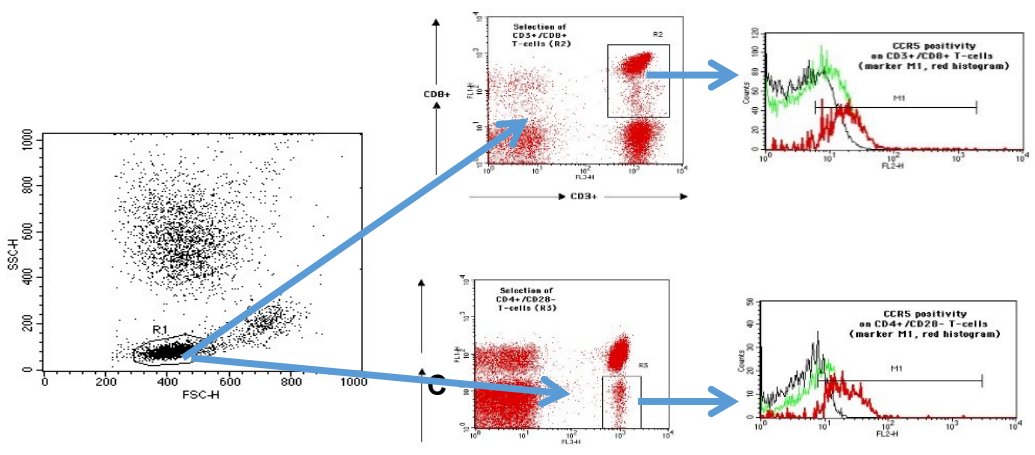

Fig 2: Flow cytometry analysis

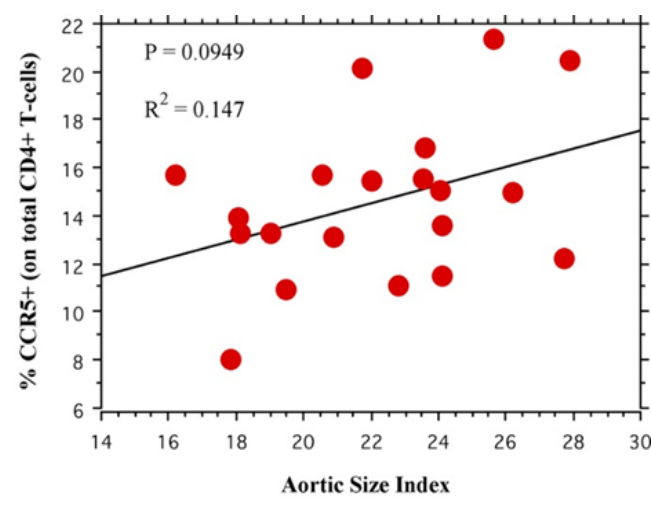

Fig 3: Correlation graph of ASI vs. CCR5 on CD4+

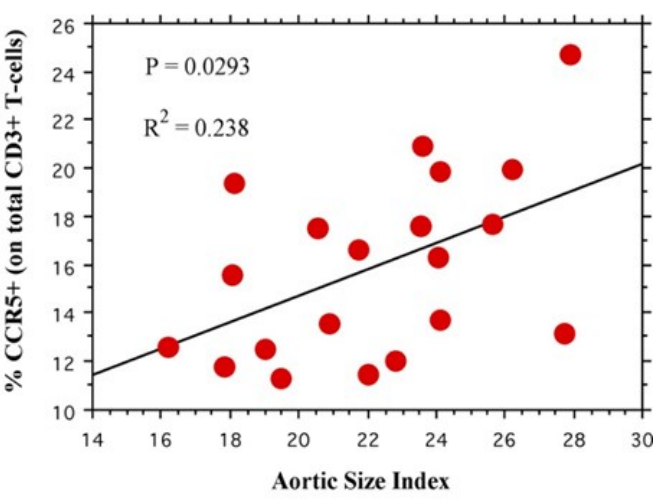

Fig 4: Correlation graph of ASI vs. $\mathrm{CCR} 5$ on $\mathrm{CD} 3+$ 
Paquinucci Heart hospital for a period of six months. Written consent and institutional ethical committee approval was taken prior to commencement of the study.

Aortic size index was calculated for every patients according to the formula proposed by Davies and co-authors. That is ascending aortic diameter divided by body surface area. ${ }^{4}$

To evaluate chemokine receptors expression on peripheral blood T- Lymphocytes subsets (CD3, CD4, CD28, CD8, TCR $\gamma \delta$ ), preoperatively we have collected blood samples from all the patients and were mixed with ammonium chloride red cell lysing solution and consecutively stained with appropriate volume of fluorescent monoclonal antibodies against the following chemokine receptors; CCR5, CXCR3, CX3CR1.

Preliminary identification of lymphocytes done using a morphological gate of Forward scatter (volume) and Side scatter (cellular complexity) flow cytometry.

Then after, two dual parameter dot plot are used to select CD8 positive cells in the R2 region and $\mathrm{CD} 28$ negative cells in the $\mathrm{R} 3$ region.

Furthermore, from the association of $\mathrm{R} 1+\mathrm{R} 2$ and $\mathrm{R} 1+\mathrm{R} 3$, histograms were derived and percentage of positivity of CCR5 on these T-cell subsets were quantified (Fig 2).

\section{RESULTS}

General characteristics of the patients are presented in the table 1. Mean age of the patients was $67 \pm 5.93$ years with sixty percentage of male patients. Majority of patients (65\%) had hypertension, while only $5 \%$ of these patients were suffering from

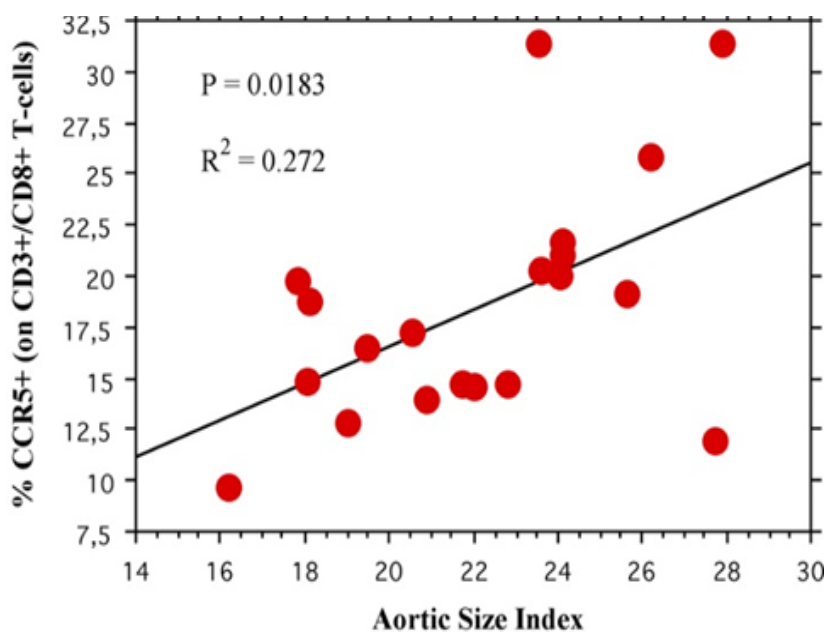

Fig 5: Correlation graph of ASI vs. CCR5 on $\mathrm{CD} 3+/ \mathrm{CD} 8+$ diabetes. Mean ascending aortic diameter was $42.1 \pm 8.14 \mathrm{~mm}$ with $70 \%$ of patients having predominant aortic regurgitation. One-third (30\%) of our patients were diagnosed with bicuspid aortic valve. Mean Aortic size Index was $22.21 \pm 3.38 \mathrm{~mm} /$ $\mathrm{m}^{2}$.

Fig 3 and 4 represent the linear regression between aortic size index and CCR 5 percentage of positivity on total $\mathrm{CD} 4+$ and on total $\mathrm{CD} 3+$ circulating $\mathrm{T}$ lymphocytes. A trend towards statistical significance has observed between aortic size index and the expression of CCR5 on total CD4 positive T-cells (p-0.0949), whereas there is significant correlation between aortic size index and CCR5 expression on the total CD3 positive T-cells (p0.0293).

In particular, a significant correlation observed between Aortic size index and CCR5 expression on the CD8+/CD3+ T-cell subset (p-0.0183) (Fig 5).

Furthermore, there is a strong positive relationship between ASI and the expression of CCR5 on the cytotoxic CD28-/CD4+ T-cell subset (p-0.0055). Moreover, activation state of cytotoxic CD28-/ $\mathrm{CD} 4+$ cell also correlated with aortic size index (p0.0668) (Fig 6, 7).

\section{DISCUSSION}

Aortic aneurysm can be defined as a localized undue dilation with $50 \%$ increase in size over the normal diameter. ${ }^{6}$ Thoracic aorta of more than $4 \mathrm{~cm}$ of diameter is distinct as aneurysmatic aorta. Thoracic aortic aneurysm remains asymptomatic for several years until it compress the neighboring structures, dissects or ruptures. Mortality from the complication is very high. So prophylactic surgery in patients with aortic aneurysm is practiced. Due to improvement in pre and postoperative care of the patients in cardiac surgery, two years survival of patients significantly improved from $24 \%$ in unoperated patients to $70 \%$ in patients undergoing aortic replacement surgery. ${ }^{7}$

All together indications for TAA surgery can be divided into two broad categories. ${ }^{9}$ Mandatory indication; it includes emergency situations as acute dissection, rupture and intramural haematoma and entails immediate treatment at the time of diagnosis. Elective indication; this is basically prophylactic in nature, it is reserved for chronic aneurysm and aims to avoid occurrence of acute, devastating complications.

In modern surgical practice, indication for elective TAA surgery depends on two instrumental 
parameters. ${ }^{8}$ Absolute diameter of aorta at the time of evaluation and yearly growth rate of aortic diameter, independently from absolute diameter. In addition, aortic size index is a new index for surgical indication. It implies that size of aorta can vary according to the body surface area and risk of dissection or rupture is closely related to it. Davies et al have proposed an "Aortic Size Index (ASI)" (aortic absolute diameter / body surface area) of $2.75 \mathrm{~cm} / \mathrm{m}^{2}$ or more should prompt to elective thoracic aortic aneurysm surgery to avoid moderate to severe $(8-20 \%)$ yearly risk of adverse events (Fig 1). For example, a $45 \mathrm{~mm}$ aneurysm in a small woman, with body surface area (BSA) of $1.4 \mathrm{~m}^{2}$, should be nowadays surgically treated, ${ }^{4}$ independent of the absolute size of the aorta.

Pathophysiology of ascending aortic aneurysm is a complex process involving four fundamental processes. These are Smooth muscle cell loss, matrix injury, Cytokine activity and chronic inflammation leading to aortic degeneration and destruction of aortic wall integrity causing dilation and ultimately dissection or rupture of the aorta. ${ }^{9}$

Cardinal feature of inflammation, tissue recruitment of leukocytes, is mediated mainly by chemokines (chemotactic cytokines) via their receptors. Chemokines are small secreted proteins, which were initially identified to regulate leukocytes trafficking during the inflammatory process. ${ }^{10}$

There are 20 chemokine receptors known to date. In addition to chemotactic activity, chemokines also implicate cell adhesion, cytokine secretion, cell activation, proliferation, phagocytosis, apoptosis, and angiogenesis. ${ }^{11}$

CCR5 is one of the important chemokine receptor, which is also a Th1 associated chemokine receptor. During the inflammatory process, it is involved in the migration and activation of monocytes, NK cells, and leukocytes trafficking into the inflammation site. They are a strong regulator of the inflammatory process in the atherosclerosis and they are also expressed on the VSMCs. ${ }^{12}$

Cytotoxic CD28-/CD4+ T-cells are highly differentiated Th1 Cells, which produce INF gamma and TNF alfa, with higher proinflammatory and tissue damaging potential. Specially, CD4+ cells with cytotoxic protein (granzyme and perforin) has direct cytotoxic effect as NK cells. These cells are equipped to migrate from the peripheral blood to tissue using chemokines receptors like CCR5 and fractalkine receptors. They also express number of NK receptors such as killer immunoglobulin receptors, killer lectin receptors. Their role in chronic inflammation, autoimmune process and vascular damage has been demonstrated in several studies. ${ }^{13,14}$

Another cytotoxic cell is CD8+ T-cell, which acts by specific recognition of the target cell and could release cytotoxic proteins, which kill cells directly. Another way of cellular damage is by Fas ligand expression and binding to the Fas receptor on the targeted cell. Like other cytotoxic cells, they also express killer lectin receptor and recognize MHC class I molecules. This recognition deliver signals, which act together with TCR to enhance killing of the cell. These cells also secrete IFN gamma, which plays defensive role against phagocytosed microbes. ${ }^{15}$

In our study, we have found significant correlation between ASI, which is a predictor for negative event in the patients with aortic aneurysm, and chemokine receptor 5 (CCR5). This shows significant destruction of the aortic wall due to inflammatory process mediated by these chemokine receptors. Furthermore, expression of other cytotoxic cells in the peripheral blood of the patient is significantly correlated with ASI.

Based on our finding from this pilot study, we conclude that T-cell mediated cytotoxic mechanism driven by CCR5 play an important role in the pathophysiology of the thoracic aortic aneurysm. Knowledge of these pathophysiological mechanisms in the development of thoracic aortic aneurysm could lead us towards development of innovative therapeutic options for this virulent and lethal disease.

\section{Limitations of this study}

Small number of patient population, non randomization of the individuals and lack of histological study of aortic tissue. In future, measurement of gene expression and protein expression of ligands specific for CCR5 into the damaged aortic tissue can be studied. If we find the higher number of ligands into the tissue, it could confirm the pathogenetic role of this chemokine receptor in thoracic aortic aneurysm pathogenesis. Moreover, immunohistochemical quantification of T-cell infiltration into the aortic specimen could further support this hypothesis and our findings drawn from the analysis of the peripheral blood of the patients. 


\section{REFERENCES}

1. Osler W. Aneurysm of the abdominal aorta. Lancet. 1905;2:1089. DOI: 10.1016/S0140-6736(01)69613-2.

2. Beckman JA. Aortic aneurysms: pathophysiology, epidemiology, and prognosis. In: Creager MA, Dzau VJ, Loscalzo J, eds. Vascular Medicine. 2006. DOI: 10.1016/ B978-0-7216-0284-4.50043-9.

3. Coady MA, Rizzo JA, Hammond GL, Mandapati D, Darr $\mathrm{U}$, Kopf GS, et al. What is the appropriate size criterion for resection of thoracic aortic aneurysms? J Thorac Cardiovasc Surg. 1997;113:476-491. DOI:10.1016/S00225223(97)70360-X.

4. Davies RR, Gallo A, Coady MA, Tellides G, Botta DM, Burke B, et al. Novel measurement of relative aortic size predicts rupture of thoracic aortic aneurysms. Ann Thorac Surg. 2006;81:169-77. DOI: 10.1016/ j.athoracsur.2005.06.026. PMID:16368358.

5. Tang PCY, Yakimov AO, Teesdale MA, Coady MA, Dardik A, Elefteriades JA, etal. Transmural inflammation by interferon-g-producing $\mathrm{T}$ cells correlates with outward vascular remodeling and intimal expansion of ascending thoracic aortic aneurysm. FASEB J. 2005;19:1528-30. DOI: $10.1096 /$ fj.05-3671 fje.

6. Ergin MA, Spielvogel D, Apaydin A, Lansman SL, McCullough JN, Galla JD, et al. Surgical treatment of the dilated ascending aorta: when and how? Ann Thorac Surg. 1999;67:1834-9. http://dx.doi.org/10.1016/S0003-4975(99)00439-7

7. Davies RR, Gallo A, Coady MA, Tellides G, Botta DM, Burke B, et al. Novel measurement of relative aortic size predicts rupture of thoracic aortic aneurysms. Ann Thorac Surg. 2006;81:169-77. DOI: 10.1016/ j.athoracsur.2005.06.026. PMID:16368358.

8. Dapunt OE, Galla JD, Sadeghi AM, Lansman SL, Mezrow CK, de Asla RA, et al. The natural history of thoracic aortic aneurysms. J Thorac Cardiovasc Surg. 1994;107:1323-33. PMID:8176976.

9. Elefteriades JA. Thoracic Aortic Aneurysm: Reading the Enemy's Playbook. Curr Probl Cardiol. 2008;33:203-77. DOI: 10.1016/j.cpcardiol.2008.01.004. PMID:18439439.

10. David J, Mortari F. Chemokine receptors. A brief review. Clin. Applied Immunol. Rev 2000;1:105-125. DOI: 10.1016/S1529-1049(00)00009-X.

11. Locati M, Bonecchi R, Corsi MM. Chemokines and their receptors: roles in specific clinical conditions and measurement in the clinical laboratory. Am J Clin Pathol. 2005;123:S82-S95.DOI: 10.1309/m6u4b816tnak4g9l.

12. Samson M, Lebbe O, Mollereau C, Vassart G, Parmentier M. Molecular cloning and functional expression of a new human CC-chemokine receptor gene. Biochemistry. 1996;35:3362-7. DOI: $\quad$ 10.1021/bi952950g. PMID:8639485.

13. Van de Berg PJ, van Leeuwen EM, ten Berge IJ, van Lier R. Cytotoxic human CD4+ T cells. Curr Opin Immunol. 2008;20:339-43. DOI: 10.1016/j.coi.2008.03.007. PMID:18440213.
14. Weng NP, Akbar AN, Goronzy J. CD28- T cells: their role in the age-associated decline of immune function. Trends Immunol. 2009;30:306-312. DOI: 10.1016/ j.it.2009.03.013. PMID:19540809.

15. Niederkorn JY. Emerging concept in CD8+ T regulatory cells. Curr Opin Immunol. 2008;20:327-31. DOI: 10.1016/ j.coi.2008.02.003. PMID:18406591. 